\title{
Applicability of Steiner hermeneutic motion in Coleman Barks' translation of Rumi
}

\author{
Zahra Amiri $^{1}$, Seyed Mahdi Araghi ${ }^{2}$, Fahime Farjami ${ }^{3}$ \\ ${ }^{1}$ Department of English Language Teaching, Birjand University, Birjand, Iran \\ ${ }^{2}$ Department of English Language Teaching and Literature, Payame Noor University, Iran \\ ${ }^{3}$ Young Researchers and Elite Club, Ahar Branch, Islamic Azad University, Ahar, Iran

\section{Email address:} \\ zahraamiri1363@yahoo.com (Z. Amiri), m_araghi@pnu.ac.ir (S. M. Araghi), fahimefarjami@yahoo.com (F. Farjami)
}

\section{To cite this article:}

Zahra Amiri, Seyed Mahdi Araghi, Fahime Farjami. Applicability of Steiner Hermeneutic Motion in Coleman Barks' Translation of Rumi. International Journal of Language and Linguistics. Special Issue: Foreign Language Teaching and Learning (Models and Beliefs).

Vol. 2, No. 3-1, 2014, pp. 42-45. doi: 10.11648/j.ijll.s.2014020301.15

\begin{abstract}
This article aims to study the applicability of Steiner hermeneutic motions in Colman Barks translation of Essential Rumi. At first, it introduces hermeneutic motions suggested by George Steiner which include initiative trust, aggression, embodiment and restitution; then studies Coleman Barks 'Translation of Rumi according to Steiner' $\mathrm{s}$ hermeneutic motion. This article shows that Barks 'translation is applicable in Steiner' hermeneutic motion. He could pass the first three motions but he fails in the fourth motion and did not meet the fidelity principle in his work. The author suggests that it is better to call his work as aversion but not atranslation.
\end{abstract}

Keywords: Hermeneutic Motion, Steiner, Colman Barks, Rumi

\section{Introduction}

Translating poetry is the most challenging translation, especially when it is a metaphysical one. Melawi's poems are of this type; and have deep and metaphysical meanings, this is the reason why it can be translated in different ways. Mawlana Jalal-ad-Din Mohammad Balkhi Rumi, Known in the U.S as Rumi was an Iranian great poet who a lot of translators have tried to translate his poems; among them Coleman Barks could produce a best-seller work in the U.S. American readers buy his translation enthusiastically and this poet of thirteen century is very popular in the U.S thanks to Barks' translation. This is the case that how could this translation achieve this popularity. Reading Barks' translation, one who knows Persian can understand that there are a lot of distortions and mistranslations in this work. In spite of all these distortions, Barks could produce a rather similar effect of the Melawi's poems on American readers. This article deals with Barks translation based on Steiner hermeneutic motion to study whether it is applicable through these motions or not.

\section{Literature Review}

Steiner believed that "every understanding is actively interpretive, even the most literal statement has a hermeneutic dimension" (Steiner, p. 295). He suggested that the hermeneutic motion consists of four motions: 1) initiative trust; 2) aggression; 3) incorporation (or embodiment) and 4) compensation.

Cui Yao in “A study on translator's subjectivity in English versions of Liozhaizhiryi under the perspective of George Steiner's hermeneutic motion" deals with subjectivity and analyzes different translation effects caused by translators' different culture backgrounds, personal experiences and other subjective matters.

AmerLatif (2009) in his dissertation"Qur'anic Narrative and Sufi Hermeneutics: R 'um's'sInterpretations of Pharaoh's Character" claims that Rumi has interpreted Quran and " $\mathrm{R}^{-} \mathrm{um}^{-} \mathrm{l}$ 's interpretive activity is motivated by a desire to guideothers and he builds on the Qur'anic teachings concerning God's mercy by pointingout to his readers that the door of forgiveness is never closed"

This article deals with Steiner hermeneutic motion applicability and selects Colman Barks translation of Rumi as a case study.

Mawlana Jalal-ad-Din Mohammad Balkhi Rumi, Known in the U.S as Rumiwas one of the greatest Persian poetsthat his translated works are best-selling recently in the U.S.

A lot of translators have translated his poems such as A.J. Arberry, William hittick,Ravan A. G. Farhadi, Daniel 
Ladinsky, Shahram Shiva, Nader Khalili, Franklin Lewis, Majid M. Naini, Reynold A. Nicholson,James W. Redhouse, but none of their translations could produce as such an effect as Barks translation had. However, it is argued that his translation in fact is not a translation and it is a kind of interpretation that Colman Barks frequently accepted this fact.

Colman Barks is an American poet who astonishingly neither can speaks nor write Persian. He has published several books of Rumi poems. Today, Rumi is well-known and alive among American society due to Barks work. But Barks' work has some proponentsand opponents. In one hand, Proponents welcome him because he introduced Rumi a poet of 700 years ago to new generation especially in western culture and explained his philosophical views in a new language. He interpreted Rumi's views and explained them in his language and it became acceptable among the American people. In other hand, opponents are dissatisfied because he has not observed the fidelity principle and distorted some facts about Rumi character and views.

However, Barks translation is very popular and it can be considered in many aspects.

In the following, the researcher studies Barks' translation step by step.

\section{Initiative Trust}

Initiative trust is the first move towards translation and as Steiner believes is the most hazardous and most pronounced one, where the translator aims to convey meaning between remote languages and cultures (ibid, p.371). In this step translator selects a text and approach it with this trust that there is something there worth translating and there is something that can be understood (ibid, p.312). He believed that in this step, translator show 'generosity' to an alien text.

In this respect, Coleman Barks has met the first movement. In spite of political differences between Iran and the U.S. he began to translate a work by an Iranian poet. However, Rumi' works have been translated before and he is a well-known character in the world. But Barks picked a big step to introduce Rumi more in the U.S.

At first, Robert Bly his close friend introduced Rumi to Barks and gave him a copy of a translation of Rumi's poetry by Arberyand said "these poems need to be released from their cages" (Lawler, 2007). Maybe it refers to Walter Benjamin' statement that " it is the task of translator to release in his own language that pure language which is under the spell of another, to liberate the language imprisoned in a work in his re-creation of that work. For the sake of pure language he breaks through decayed barriers of his own language" (Benjamin, 1923, p.82). Barks accepted his suggestion and began to live with Rumi's poems and spent 7 years working on them. All in all, Barks passed the first stepsuccessfully and put his trust in Rumi and worked rather sincerely to introduce him and spread his ideas among American society.

\section{Aggression}

The second step is a dynamic step, aggression, the translator takes over, captures the foreign text. The translator enters the text, extracts meaning and takes it away.

According to Steiner, comprehension in translation is invasive and exhaustive. "The translator invades, extracts and brings home" (Steiner, p.314). Melawi's poems have metaphysical and deep meanings, he posited different spiritual concepts in his poems. These concepts attract the today people who are in need for spiritual concepts.

Knowing the need of "spiritual hunger", Barks explored and extracted those meanings and brought them to his home.

Before him, some translators such as R. A. Nicholson, A. J. Arberry, Annemarie Schimmel, William Chittick, and Franklin Lewis have translated Rumi's works literally, but none of them could leave the effect that Barks' work had.

He frequently avowed that he does not know Persian and he has used the translation of Arbery "I translate it into American free verse). "Someone brings it from the source language sort of halfway to a literal translation and then someone else takes it from that stage to a poem in the English language"“(Barks,2007).

Considering this fact that he has never touched the original work and just interpreting his own interpretation from the translation and rendering them to his language shows an invasive act. It takes a lot of courage to do such a risky job and "Scholarly translations don't try to do that" as Barks himself contends (Barks,2007).

In all, Barks extracts the intended favorable meanings of Rumi poems. In this motion, Barks acts as Steiner suggested.

\section{Incorporation (or Embodiment)}

The third movement is incorporative, "the import, of meaning and of form, the embodiment, is not made in or into a vacuum" (Steiner, p.314). This taken away meaning is brought into the TL. The text becomes part of the translator's language, As Steiner states: "No language, no traditional symbolic set or cultural ensemble imports without risk of being transformed." (ibid, p.315). In this step, the translator realizes and tries to convey what he or she understands in his or her own language.

In this movement, target language is focused and domestication happens. As Melawi poems are about happiness, love, equality, positivism and prevention of prejudice, they are the best concepts to attract American readers and Barks focused on them and he shows this in his selection of Melawi works. It is the balance that has made the work more enriched and hence popular.

Altogether, Barks imports Rumi's ideas successfully into the western culture. In this motion,again Barkscould act as Steiner stated in his hermeneutic motions. 


\section{Compensation (Restitution)}

In his fourth movement, compensation or restitution, Steiner suggests a movement to compensate what has been taken away. The translator restores something to the target text to compensate. The Translator tries to establish a balance between the target text and the source text which had been disrupted by the translator's interpretive attack (ibid, p.318).

In this step, Steiner emphasized on the fidelity principle, and confessed that the hermeneutic motion is incomplete without this step. He had a different idea towards fidelity and states that "fidelity is not literalism or any technical device for rendering 'spirit'. He believes that "fidelity is ethical, but also, in the full sense, economic. By virtue of tact, and tact intensified is moral vision, the translator interpreter creates a condition of significant exchange. The arrows of meaning, of cultural, psychological benefaction, move both ways. There is, ideally, exchange without loss (ibid, pp.318, 319).

In this motion, Barks fails because he "not only "frees" Rumi from the historical limitations of his time but he also tries to disconnect Rumi from the Islamic society in which he lived and the Persian language in which he wrote his poetry" (Naficy,2005).

Steiner states that "translation fails where it does not compensate, where there is no restoration of radical equality" (Steiner,p.417).

At first glance, Barks gave another name to the poet. He called Melawi as Rumi. In fact, he created a new character, a new version of Melawi works by capturing the spirit of his poems. He didn't translate a full book and selected those poems that he thought they are according toAmerican readers' taste.

Melawi's love poems are of a sort of spiritual love not the earth one; but Barks showed it as an earth love and his mistranslations have caused a lot of misunderstanding about Melawi's character; and made some homosexual people think thatMelawi's love to his professor and friend is of that kind. Whereas, "Rumidoes not refer to love in its narrow sense, that is, theoutcome of the sexual experience and pleasure. Tohim love relates more to care, concern, intimacy, andtotal expression. "(Arasteh, p.161)

These responses and views were criticized strongly by some of the famous Iranian authors like Hassan Lahuti (2013) and MajidNafisy (2005).

Also, American reader can not enjoy the special rhythm and dynamic of Melawi's poems and they just became aware of some of his ideas. One can justify Barks' distortion to convey Melawi's great concepts to ordinary people to enjoy of them.

Melawi has a special character and did not care about fame; and as he said in one of his poems

$$
\text { هركسيازظنخو دشديار مناز درونمننجستاسر ارمن }
$$

(Everyone thinks that could be my companion)
But no one could understand my hidden secrets

If we rely on this stanza, we can accept Barks translation. The translator has compensated for the loss while translating from source text to target text by introducing Melawi a 13th century poet to the new generation and conveying his ideas in a today language and taste.

This has helped the translation enter into a new culture of target text which has received the translation well and hence the popularity of the book. In this regard, both the source text and the target text are enriched. "translation is presented as a process in which various aspects and elements are considered by the translator to achieve a goal, which is seldom perfectly realized". (Naude, 2010)

\section{Conclusion}

This article aimed to study the applicability of Steiner hermeneutic motions in Colman Barks translation of Essential Rumi. After studying Bark's translation, it showed that the hermeneutic motions suggested by Steiner are applicable and Barks could pass the first three motions including: trust, aggression and embodiment; but he failed to meet the fourth motion, compensation. In fact, it is not a translation but it is a kind of adaptation, a version of Melawi's works. The author suggests that Iranian practitioners especially poems who are called Melawiknower try to deliver a better translation which deserve Melawi status.

\section{References}

[1] Arasteh,A.Reza. (1974). The Persian, The Sufi. London and New York: Routlege.

[2] Barks, C. (1995). The essential Rumi .New York: HarperCollins.

[3] Barks, C. (2007).Coleman Barks, foremost Rumi translator, talks about the Persian mystic's timeless appeal and his own spiritual life. [Interview with David Ian Miller]. Journal of SFGate. Retrieved from http://www.sfgate.com/living/article/Coleman-Barksforemost-Rumi-translator-talks-2537796.php

[4] Benjamin, Walter. (1923). The task of the translator. In: L. Venuti, (Eds.).'The TranslationStudies Reader' (pp. 75-83). London, New York: Routledge.

[5] Lahuti, H. (2013). In Persian house. No.2.retrieved fromhttp://persiahousemi.org/Docs/Faslnameh_Summer_20 13.pdf.

[6] Latif,A. (2009). Qur'anic Narrative and Sufi Hermeneutics: $\mathrm{R}^{-} \mathrm{um}^{-}{ }^{-1}$ 's Interpretations of Pharaoh's Character. (Doctoral dissertation).Retrieved from https://dspace.sunyconnect.suny.edu/bitstream/handle/1951/ 48327/000000597.sbu.pdf?sequence=2

[7] Lawler, Andrew. (2007). Walking around in the heart. The sun magazine. Retrieved from http:/www.thesunmagazine.org/issues/382/walking_around_ in_the_heart. 
[8] Naficy, M. (2005). Retrieved from http:/www.Iranian.com/NaficyMajid/2006/December/Barks/ index.html.

[9] Naude, Jacobus.

(2010). Sinergy. (Eds). Amesterdam/Philadelphia: John Benjamins Publishing Company.
[10] Steiner, George. (1973). After Babel: Aspects of language and translation. London: OxfordUniversity Press. 